\title{
Grape-Derived Polyphenolics Prevent A $\beta$ Oligomerization and Attenuate Cognitive Deterioration in a Mouse Model of Alzheimer's Disease
}

\author{
Jun Wang, ${ }^{1}$ Lap Ho, ${ }^{1,4}$ Wei Zhao, ${ }^{1}$ Kenjiro Ono, ${ }^{3}$ Clark Rosensweig, ${ }^{3}$ Linghong Chen, ${ }^{1}$ Nelson Humala, ${ }^{1}$ \\ David B. Teplow, ${ }^{3}$ and Giulio M. Pasinetti ${ }^{1,2,4}$ \\ Departments of ${ }^{1}$ Psychiatry and ${ }^{2}$ Neuroscience, Mount Sinai School of Medicine, New York, New York 10029, ${ }^{3}$ Department of Neurology, David Geffen \\ School of Medicine, Brain Research Institute, and Molecular Biology Institute, University of California, Los Angeles, Los Angeles, California 90095, and \\ ${ }^{4}$ Geriatric Research Education and Clinical Center, James J. Peters Veterans Affairs Medical Center, Bronx, New York 10468
}

\begin{abstract}
Alzheimer's disease $(\mathrm{AD})$ is a neurodegenerative disorder characterized by progressive impairments in memory and cognition. Extracellular accumulation of soluble high-molecular-weight (HMW) A $\beta$ oligomers has been proposed to be largely responsible for AD dementia and memory deficits in the Tg2576 mice, a model of AD. In this study, we found that a naturally derived grape seed polyphenolic extract can significantly inhibit amyloid $\beta$-protein aggregation into high-molecular-weight oligomers in vitro. When orally administered to Tg2576 mice, this polyphenolic preparation significantly attenuates AD-type cognitive deterioration coincidentally with reduced HMW soluble oligomeric $A \beta$ in the brain. Our study suggests that grape seed-derived polyphenolics may be useful agents to prevent or treat $\mathrm{AD}$.
\end{abstract}

Key words: Alzheimer's disease; $\mathrm{A} \beta$ peptide; amyloid $\beta$; cognitive; dementia; Morris water maze; spatial memory

\section{Introduction}

Recent epidemiological and experimental evidence suggests that moderate consumption of red wine may reduce the incidence of $\mathrm{AD}$ and attenuate $\mathrm{AD}$-type cognitive deterioration and amyloid neuropathology (Dorozynski, 1997; Orgogozo et al., 1997; Luchsinger et al., 2004; Wang et al., 2006). Moreover, studies suggest that grape-derived polyphenolic compounds may inhibit oligomerization of A $\beta$ (Porat et al., 2006). Such inhibition would be highly significant, because accumulation of soluble extracellular high-molecular-weight (HMW) oligomeric $\mathrm{A} \beta$ species in the brain currently is considered a major risk factor for the onset and progression of cognitive deterioration in AD (Oda et al., 1995; Lambert et al., 1998; Klein et al., 2001, 2004; Selkoe, 2001; Hardy and Selkoe, 2002; Klyubin et al., 2005). Thus, pharmacological strategies for the prevention of $\mathrm{A} \beta$ oligomerization in the brain might result in improved cognitive function in $\mathrm{AD}$.

Recently, we found that moderate consumptions of the red wine cabernet sauvignon (Vitis vinifera) promoted $\mathrm{A} \beta$-lowering activity in vivo coincidentally with attenuation of spatial memory impairment in Tg2576 mice that model AD (Wang et al., 2006).

Received Sept. 27, 2007; revised May 3, 2008; accepted May 15, 2008.

This work was supported by National Center for Complementary and Alternative Medicine (NCCAM) P01 AT004511-01 Project 1 (L.H.); NCCAM P01 AT004511-01 Project 3, Department of Veterans Affairs Merit Review grant, James J. Peters Veterans Affairs Medical Center Geriatric Research Education Clinical Center Program, and Polyphenolics (G.M.P.); Japan Human Science Foundation (K.0.); and National Institutes of Health Grant AG027818 and Alzheimer's Association (D.B.T.). We thank Margaret M. Condron for peptide synthesis and purification.

Correspondence should be addressed to Dr. Giulio M. Pasinetti, Icahn Research Institute, Mount Sinai School of Medicine, 1425 Madison Avenue, Box 1230, New York, NY 10029. E-mail: giulio.pasinetti@mssm.edu.

DOI:10.1523/JNEUROSCI.0364-08.2008

Copyright $\odot 2008$ Society for Neuroscience $\quad$ 0270-6474/08/286388-05\$15.00/0
We identified wine polyphenolic compounds as the major components responsible for $A \beta$-lowering activity in the red wine. Based on this observation and the fact that the majority of polyphenolic compounds found in red wine are derived from grape seed and skin, we explore the potential development of a commercially available grape seed polyphenolic extract [MegaNatural grape seed polyphenolic extract (GSPE); Polyphenolics] as a nutraceutical alternative to moderate red wine consumption to attenuate $\mathrm{AD}$-type cognitive deterioration. GSPE is a highly purified and well characterized water-soluble polyphenolic preparation from the seeds of Vitis vinifera. Our studies' intent is to develop a highly tolerable, nontoxic, orally available reagent for the prevention and treatment of $\mathrm{AD}$ dementia.

\section{Materials and Methods}

MegaNatural GSPE. MegaNatural GSPE is a highly purified 100\% watersoluble polyphenolic extract from Vitis vinifera grape seeds (Polyphenolics). The geographic source of the grape seeds used to generate MegaNatural GSPE is California, where grapes are usually harvested between August and October. The GSPE extraction procedure is based on standard procedures at Polyphenolics. Specifically, the solvent used for the extraction of the raw material in the form of dried seeds is water for $2 \mathrm{~h}$ at $\sim 200-210^{\circ} \mathrm{F}$, and the ratio of fresh grape/seeds to finished extract is 30-50:1. No excipients are used in the extraction procedure, and the native extract is $100 \%$ from seeds. Finished product is spray dried into a powder and contains $>90 \%$ total polyphenols as gallic acid equivalents and moisture content of $<10 \%$. GSPE is stable in the factory-sealed container at room temperature for at least 3 years.

HPLC analysis shows that MegaNatural GSPE is comprised of catechin and epicatechin in monomeric, oligomeric, and polymeric forms (supplemental Fig. $1 A$, available at www.jneurosci.org as supplemental ma- 
terial). Typically, MegaNatural GSPE contains 8\% monomers, $75 \%$ oligomers, and $\sim 17 \%$ polymers. We arbitrarily used the molecular weight of catechin and epicatechin dimer (which is the most abundant form of oligomer in GSPE) to calculate the molarity for GSPE in this study. A unique feature of this extract is that it is readily absorbed through the intestinal mucosa because of the modification of the constituent polyphenols (Siva et al., 2006). Moreover, MegaNatural GSPE extract is well tolerated in both humans (Dr. A. Shrikhande, personal communication) and rodents (Bentivegna and Whitney, 2002).

Given the difficulty of reproducing the nutraceuticals consistently, we tried two different lots (lot \#25952501-30 and lot \#05642505-1), and both lots showed similar chemical profiles by normal-phase HPLC (data not shown) and reproducibly prevented $\mathrm{AD}$-type $\mathrm{A} \beta$ aggregation in vitro (data not shown). For the in vivo study, we used lot \#25952501-30.

In vitro $A \beta_{1-40}$ and $A \beta_{1-42}$ aggregation assay. $\mathrm{A} \beta_{1-40}$ and $\mathrm{A} \beta_{1-42}$ peptides were purchased from American Peptide or synthesized chemically. For Western blotting, peptides were solubilized in hexafluoroisopropanol (Sigma) and dried overnight (Klein, 2002). GSPE stock was dissolved in phosphate buffer, pH 7.4 (Invitrogen), at $200 \mu \mathrm{M}$. $\mathrm{A} \beta_{1-40}$ and $\mathrm{A} \beta_{1-42}$ $(100 \mu \mathrm{g} / \mathrm{ml}$ in PBS) were mixed with different concentrations of GSPE at 1:1 volume and incubated at $37^{\circ} \mathrm{C}$ for $24 \mathrm{~h}$. The effect of GSPE on $\mathrm{A} \beta$ aggregation was analyzed by Western blot analysis using $6 \mathrm{E} 10$ antibody.

Photo-induced cross-linking of unmodified proteins assay. Freshly isolated low-molecular-weight $\mathrm{A} \beta_{1-42}(10-20 \mu \mathrm{M})$ or $\mathrm{A} \beta_{1-40}(30-40 \mu \mathrm{M})$ peptide was mixed with $1 \mu \mathrm{l}$ of $1(1 \times), 2(2 \times), 5(5 \times)$, or $10(10 \times) \mathrm{mm}$ tris(2,2'-bipyridyl)dichlororuthenium(II) [Ru(Bpy)] and $1 \mu \mathrm{l}$ of 20 $(1 \times), 40(2 \times), 100(5 \times)$, or $200(10 \times) \mathrm{mm}$ ammonium persulfate (APS) in the presence or absence of $50 \mu \mathrm{M}$ GSPE in $10 \mathrm{~mm}$ phosphate, $\mathrm{pH}$ 7.4. The mixture was irradiated for $1 \mathrm{~s}$ and quenched immediately with $10 \mu \mathrm{l}$ of Tricine sample buffer (Invitrogen) containing 5\% $\beta$-mercaptoethanol (Bitan et al., 2001). The reaction was subjected to SDS-PAGE and visualized by silver staining (SilverXpress; Invitrogen).

Tg2576 mice and GSPE treatment. In this study, we used Tg2576 AD transgenic mice (catalog \#001349; Taconic). In this Tg2576 AD mouse model, $A \beta$ peptide content in the brain accumulates exponentially between 7 and 15 months of age (Hsiao et al., 1996; Kawarabayashi et al., 2001). Therefore, we treated animals for 5 months, starting at 6 (for behavioral testing) and 10 (for neuropathology and mechanistic study) months of age.

Adult female Tg2576 mice, which have a more robust plaque neuropathology (Callahan et al., 2001) and low mortality rate compared with the male Tg2576 mice, were assigned to two different groups: the GSPE treatment group and the water control group. The same kind of Tg2576 female mice were also used in our previous study on cabernet sauvignon (Wang et al., 2006). Mice were fed with $200 \mathrm{mg} / \mathrm{kg} / \mathrm{d}$ GSPE delivered in their drinking water, which is equivalent to a human dose of $1 \mathrm{~g} / \mathrm{d}$ using Food and Drug Administration criteria for converting drug equivalent dosages across species (http://www.fda.gov/cber/gdlns/dose.htm). Animals had ad libitum access to the liquid and standard chow. Drinking solutions were changed every $3 \mathrm{~d}$. After 5 months of treatment, mice were anesthetized with the general anesthetic ketamine $\mathrm{HCl}$ and xylazine (Fort Dodge Animal Health) and killed by decapitation. Brains were harvested as described previously (Wang et al., 2005). All animal studies were approved by the Institutional Animal Care and Use Committee of Mount Sinai School of Medicine.

Behavioral assessment of cognitive functions by Morris water maze test. Spatial learning memory was assessed by the Morris water maze behavioral test, as described previously (Morris, 1984). In this assay, mice were tested in a $1.25 \mathrm{~m}$ circular pool filled with water mixed with nontoxic white paint (Dick Blick Art Materials). Mice were trained to mount a hidden/submerged $(1.5 \mathrm{~cm}$ below water surface $)$ escape platform $(14 \times 14 \mathrm{~cm})$ in a restricted region of the pool. Spatial memory is assessed by recording the latency time for the animal to escape from the water onto a submerged escape platform as a function of the number of learning trials during the learning phase. Twenty-four hours after the learning phase, mice were subjected to a $45 \mathrm{~s}$ probe trial wherein the escape platform was removed. The water maze activity was monitored with the San Diego Instrument Poly-Track video tracking system.
Assessment of AD-type amyloid neuropathology. Total $\mathrm{A} \beta_{1-40}$ or $\mathrm{A} \beta_{1-42}$ in the brain were quantified by sandwich ELISA (BioSource), as described previously (Wang et al., 2005). Stereological assessment of ADtype amyloid burden in Tg2576 mice was analyzed as described previously (Wang et al., 2005). Briefly, 4\% paraformaldehyde-fixed brain was sectioned, and every 15 th section was selected from a random start position and processed for thioflavin-S staining. The amyloid burden was estimated using the Cavalieri principle with a small-size grid $(50 \times 50$ $\mu \mathrm{m})$ for point counting. Estimates of plaque volume were obtained using a systematic random sampling procedure at $40 \times$ magnification.

Brain soluble $A \beta$ oligomer analysis. The level of soluble $A \beta$ oligomers was measured both by dot blot assay and Western blot analysis (McLaurin et al., 2006) and was also quantified by ELISA. Briefly, soluble amyloid peptide was extracted in PBS supplemented with protease inhibitor mixture stock ( $25 \times$ aqueous solution; Roche Applied Science). After centrifugation at $78,500 \times g$ for $1 \mathrm{~h}$ at $4^{\circ} \mathrm{C}$, the supernatant was analyzed. Five micrograms of total protein were spotted on nitrocellulose membrane and probed with antibody A11 (Biosource), specific for oligomeric forms of $\mathrm{A} \beta$. The immunoreactive signals were visualized using enhanced chemiluminescence detection (Pierce) and quantified densitometrically (Quantity One; Bio-Rad). The same sample was also used for Western analysis. Seventy-five micrograms of total proteins were separated by $10-20 \%$ Tris-Tricine gel, transferred to a nitrocellulose membrane, and probed with either antibody $6 \mathrm{E} 10$ (Signet) or A11. Immunoreactive signals were visualized and quantified. For quantitative oligomeric $\mathrm{A} \beta$ analysis, the same sample was applied to a commercially available ELISA kit that specifically detects aggregated $\beta$ amyloid using protocols provided by the manufacturer (Invitrogen).

$A P P$ processing and $\alpha$-, $\beta$-, and $\gamma$-secretase activity. Expression of holoamyloid precursor protein (APP) was examined by Western blot analysis with the C8 antibody. Immunoprecipitation was performed for detection of soluble APP (sAPP)- $\alpha$ or sAPP- $\beta$ as described previously (Wang et al., 2005). $\alpha$-, $\beta$-, and $\gamma$-secretase activities were assessed using commercially available kits (R\&D Systems) (Ho et al., 2004; Wang et al., 2005). The expression of neprilysin and insulin-degrading enzyme (IDE) were analyzed by Western blot using commercially available antibody (IDE antibody from Abcam and neprilysin antibody from Alpha Diagnostic International).

Statistical analysis. All values are expressed as mean and SEM. Differences between means were analyzed using either two-way repeatedmeasures ANOVA or two-tailed Student's $t$ test. In all analyses, the null hypothesis was rejected at the 0.05 level. All statistical analyses were performed using the Prism Stat program (GraphPad Software).

\section{Results}

\section{GSPE prevents $\mathrm{A} \beta$ peptide oligomerization in vitro}

In initial in vitro studies, we found that GSPE prevented formation of SDS-stable oligomers of synthetic $\mathrm{A} \beta_{1-42}$ (Fig. $1 A$ ) or $\mathrm{A} \beta_{1-40}$ (Fig. $1 B$ ) in a dose-dependent manner. To probe effects on initial peptide oligomerization, oligomer size distributions were determined using the photo-induced cross-linking of unmodified proteins (PICUP) technique (Fig. 1C,D) (Vollers et al., 2005). Inhibition of oligomerization was observed for both peptides in the PICUP analysis. Noteworthy was the almost complete inhibition of $\mathrm{A} \beta_{1-42}$ oligomerization (Fig. $1 C$ ). Our studies show that GSPE inhibits formation of soluble HMW A $\beta$ species and low-order oligomers.

\section{GPSE treatment lowers brain amyloid neuropathology by preventing oligomerization of $\mathrm{A} \boldsymbol{\beta}$ peptide in $\mathrm{Tg} 2576$ mice}

Based on the reported average daily consumption of $1 \mathrm{~g}$ of proanthocyanidin and related phenolics by North Americans (Scalbert and Williamson, 2000), we treated adult Tg2576 AD mice with $200 \mathrm{mg} / \mathrm{kg} / \mathrm{d}$ of GSPE, equivalent to a human dosage of $1 \mathrm{~g} / \mathrm{d}$. Consistent with previous clinical and experimental evidence (Vinson et al., 2001; Bentivegna and Whitney, 2002), GSPE treatment delivered in the drinking water for 5 months 
A
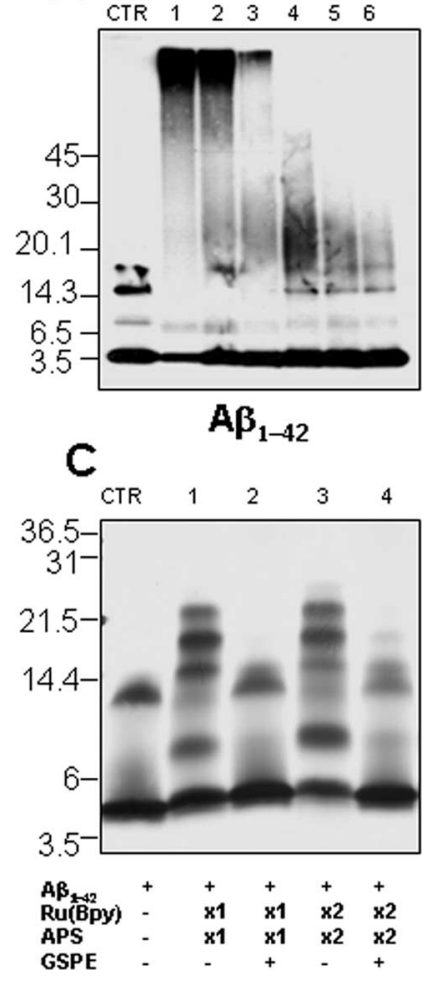

B
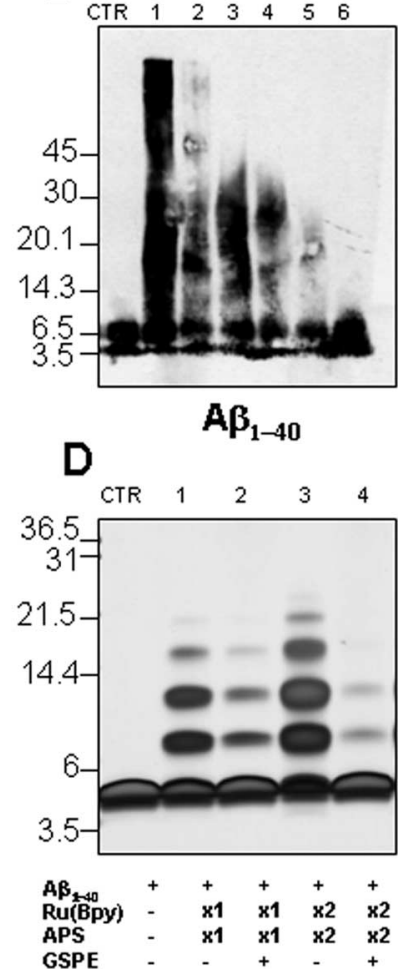

Figure 1. GSPE attenuates aggregation of $A \beta$ peptides into soluble oligomeric forms in vitro. $\boldsymbol{A}, \boldsymbol{B}$, Dose-dependent inhibition by GSPE of synthetic $A \beta_{1-42}$ or $A \beta_{1-40}$ peptide aggregation into HMW oligomeric $A \beta$ forms. $A \beta_{1-42}$ (final concentration $50 \mu \mathrm{g} / \mathrm{ml}$ ) or $A \beta_{1-40}$ (final concentration $50 \mu \mathrm{g} / \mathrm{ml}$ ) peptide was incubated with various concentrations of GSPE [lanes $1-6,0$, $0.2,1,5,25$, and $100 \mu \mathrm{m}$; CTR (control) are samples without incubation] at $37^{\circ} \mathrm{C}$ for $24 \mathrm{~h}$. Bands were visualized by Western blot analysis probed with 6 E10 antibody. C, D, SDS-PAGE of A $\beta_{1-42}$ and $A \beta_{1-40}$ in the presence or absence of GSPE after PICUP (see Materials and Methods). $A \beta_{1-42}$ or $A \beta_{1-40}$ was cross-linked in the presence or absence of $50 \mu \mathrm{m}$ GSPE, and the bands were visualized using silver staining. CTR, Non-cross-linked $A \beta_{1-42}(\boldsymbol{C})$ or $A \beta_{1-40}(\boldsymbol{D})$; lanes 1 and $2, A \beta$ peptide with $1 \times \mathrm{Ru}(\mathrm{Bpy})$ and $A P S$ in the absence and presence of GSPE; lanes 3 and $4, A \beta$ peptide with $2 \times \mathrm{Ru}(\mathrm{Bpy})$ and APS in the absence and presence of GSPE. The data are representative of results obtained in each of three independent experiments. The $\sim 13.5 \mathrm{kDa}$ (trimer) bands are an SDS-induced artifact (Bitan et al., 2003).

did not result in detectable adverse effects, including changes in body weight (Fig. 2A) or water consumption (Fig. 2B). Normal liver functions were observed in both GSPE-treated and water-treated control groups, as reflected by normal serum levels of aspartate aminotransferase and alanine aminotransferase (data not shown).

Mice were examined for neuropathology after 5 months of treatment (Fig. $1 C-F$ ). We observed an $\sim 30-50 \%$ decrease in oligomerization of $A \beta$ peptides into HMW $A \beta$ species, as assessed by immunodot blot assay using an antibody specific for $\mathrm{A} \beta$ oligomers $(p<0.05)$ (Fig. $2 C$ ) or by Western blot using A11 antibodies $(p<0.01)$ (Fig. $2 D)$. We found that the reduction of HMW A11-immunoreactive oligomeric $\mathrm{A} \beta$ species in the brain of Tg2576 mice coincided with a commensurate elevation of monomeric $\mathrm{A} \beta$ peptides $(p<0.05)$ (Fig. $2 D)$, supporting the hypothesis that GSPE might beneficially influence AD through the prevention of $A \beta$ oligomerization. Consistent with this observation, quantitative analysis using ELISA assay showed that the oligomeric $\beta$ amyloid in GSPE-treated animal brains was significantly reduced, by $\sim 30-35 \%(0.68 \pm 0.07 \mathrm{ng} / \mathrm{mg}$ protein in control animals vs $0.48 \pm 0.05 \mathrm{ng} / \mathrm{mg}$ protein in GSPE-treated animals).

Recent observations suggest that the prevention of $\mathrm{A} \beta$ oligomerization into HMW species in the brain may lead to compensatory reductions in total $\mathrm{A} \beta$ peptides and eventually amyloid neuritic plaque content in the brain, possibly as a result of preferential clearance of monomeric $A \beta$ peptides from the brain relative to oligomeric $\mathrm{A} \beta$ species (Morelli et al., 2005). Consistent with this hypothesis, we found that in addition to reducing levels of HMW oligomeric A $\beta$ species (Fig. 2C,D), long-term GSPE treatment also significantly decreased the amounts of $\mathrm{A} \beta_{1-42}$ (Fig. $2 E$, left) and $\mathrm{A} \beta_{1-40}$ (Fig. $2 E$, right) peptides and amyloid neuritic plaque burden (Fig. $2 F$ ), relative to age- and gendermatched water-treated control mice.

In control studies, we evaluated potential mechanisms that also could have contributed to the beneficial effects of GSPE on amyloid neuropathology. We found no detectable changes in the content of holo-APP (supplemental Fig. $2 \mathrm{~A}$, available at www. jneurosci.org as supplemental material), nor did we find any changes in the enzymatic activities of $\alpha$-, $\beta$-, and $\gamma$-secretase or the content of soluble APP $\alpha$ and soluble APP $\beta$ (supplemental Fig. $2 B, C$, available at www.jneurosci.org as supplemental material). Moreover, we found no detectable changes in the content of neprilysin (supplemental Fig. 2D, available at www.jneurosci.org as supplemental material) or IDE (supplemental Fig. 2E, available at www.jneurosci.org as supplemental material), which are the main proteolytic enzymes responsible for $A \beta$ degradation. Finally, we observed no detectable change in the levels of $\mathrm{A} \beta_{1-42}$ and $\mathrm{A} \beta_{1-40}$ peptides in peripheral serum (supplemental Fig. $2 F$, available at www.jneurosci.org as supplemental material). Our studies suggest that GSPE might exert its beneficial effect in vivo primarily through the prevention of $A \beta$ oligomerization into soluble HMW species, as found in vitro.

\section{GSPE treatment attenuates amyloid-associated cognitive impairments in Tg2576 mice}

The accumulation of oligomeric $\mathrm{A} \beta$ in the brain may promote AD-type cognitive impairment (Oda et al., 1995; Lambert et al., 1998; Klein et al., 2001; Cleary et al., 2005; Klyubin et al., 2005). Our study suggested that GSPE was effective in preventing A $\beta$ oligomerization in vitro, as well as in vivo (Figs. 1,2 ). We hypothesized that treatment of Tg2576 mice with GSPE should functionally attenuate $\mathrm{AD}$-type cognitive deterioration. Thus, Tg2576 mice were treated with GSPE for 5 months, and cognitive function was assessed at 11 months of age, when $\operatorname{Tg} 2576$ mice are normally characterized by AD-type spatial memory deficits (Hsiao et al., 1996). Consistent with previous evidence (Hsiao et al., 1996), we found significant spatial reference memory function impairments in 11-month-old Tg2576 mice during learning trials in a Morris water maze test (Fig. 3A). Conversely, we found that GSPE-treated Tg2576 mice performed significantly better, as reflected by significant reductions in escape latency time with progressive learning trials (two-way repeated-measures ANOVA; GSPE vs control group: $F_{(1,11)}=4.90, p=0.049$ for GSPE treatment; $F_{(7,77)}=4.25, p=0.0005$ for time; and $F_{(7,77)}=1.63, p=$ 0.140 for interaction) (Fig. $3 A$ ). GSPE-induced attenuation of cognitive impairment in Tg2576 mice was confirmed in the probe trial showing that GSPE-treated mice spent significantly more time in the target quadrant area relative to water-treated control mice (Fig. 3C) as well as an increased number of crossings over the exact location of the platform (Fig. 3D). This effect was not attributable to the presence of motor deficits, because the two groups of mice exhibited similar swim speeds (Fig. 3B). This cognitive function improvement coincided with a significant reduction of HMW oligomeric A $\beta$ species in the brain of GSPE- 
A

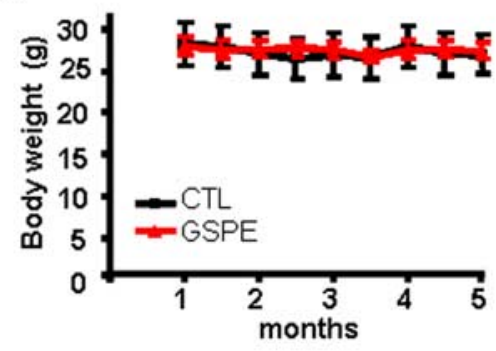

C

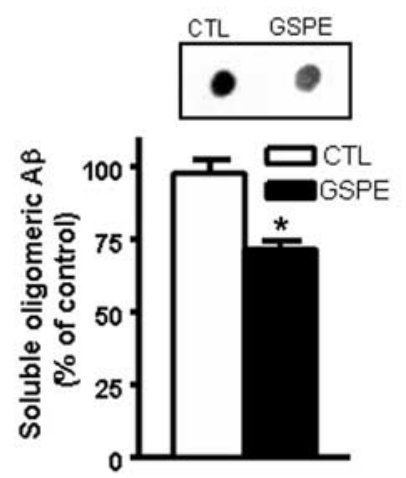

E

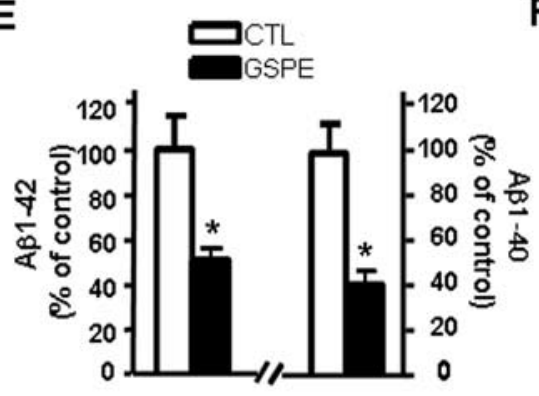

B

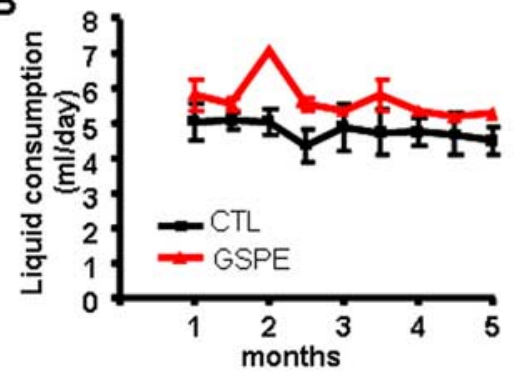

D

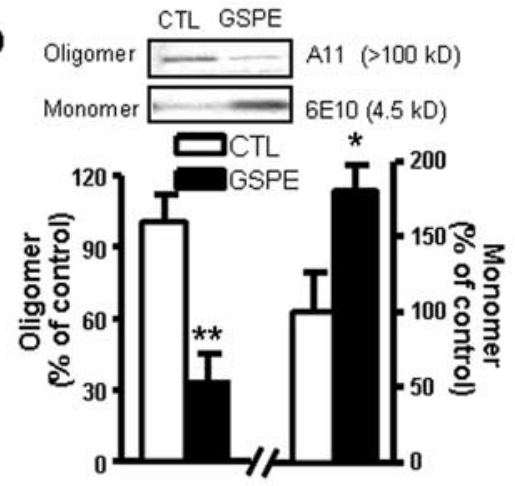

$\mathbf{F}$

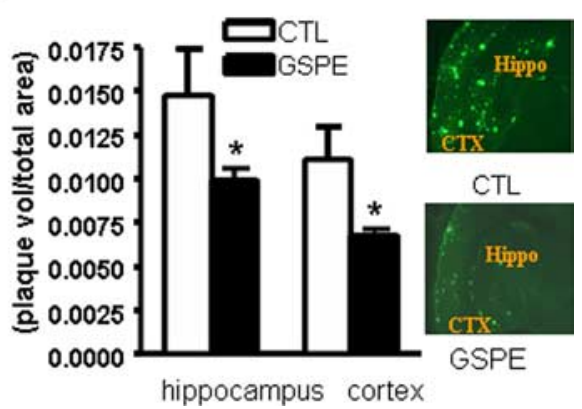

Figure 2. Chronic treatment of Tg2576 mice with GSPE prevents amyloid neuropathology by prevention of A $\beta$ oligomerization. $\boldsymbol{A}, \boldsymbol{B}$, GSPE has no effect on body weight $(\boldsymbol{A})$ or liquid consumption $(\boldsymbol{B})$ in Tg2576 mice after 5 months of treatment. $\boldsymbol{C}$, Assessments of PBS-soluble, extracellular HMW A $\beta$ peptide content in the brain using an antibody (A11) specific for HMW oligomeric $A \beta$ peptides in a dot blot analysis. C, Inset, Representative dot blot analysis of HMW soluble $A \beta$ contents. $D$, Western blot analysis of soluble extracellular HMW oligomeric $A \beta$ peptide (antibody A11) and monomeric $A \beta$ peptide (antibody $6 \mathrm{E} 10$ ) in the brain of Tg2576 mice. $E$, Assessment of $A \beta_{1-42}$ and $A \beta_{1-40}$ peptide concentrations in the brain of GSPE-treated or control mice. $\boldsymbol{F}$, Stereological assessment of cerebral cortex and hippocampal formation $A \beta$ amyloid plaque burden in GSPE-treated or control mice expressed as thioflavin-S-positive volume as a percentage of regional volume. $\boldsymbol{F}$, Inset, Representative photographs of thioflavin-S-positive $A \beta$ amyloid plaque neuropathology in neocortex (CTX) and hippocampal formation (Hippo) in untreated control (top) and GSPE-treated (bottom) Tg2576 mice. Values represent group mean \pm SEM. $n=5-8$ mice per group. ${ }^{*} p<$ $0.05,{ }^{* *} p<0.01$ by two-tailed Student's $t$ test analysis. CTL, Control.

treated Tg2576 mice relative to the control mice (Fig. 3E). In control studies, we found that GSPE treatment did not influence cognitive function in strain-, age-, and gender-matched wildtype animals (supplemental Fig. 3, available at www. jneurosci.org as supplemental material), suggesting that GSPE may benefit spatial memory reference deficits in Tg2576 mice selectively through the attenuation of $\mathrm{AD}$-type $\mathrm{A} \beta$-mediated brain injury.

Grape-derived polyphenolic compounds have been shown to have powerful antioxidant and anti-inflammatory effects (Percival and Sims, 2000; Weinreb et al., 2004), which could also contribute to the overall benefits we observed in this study.

\section{Discussion}

Alzheimer's disease is a growing public health concern with devastating impacts. A major hallmark of $\mathrm{AD}$ is the accumulation of

neurotoxic $\mathrm{A} \beta$ peptides and their extracellular plaque depositions. Recent studies indicate that extracellular accumulation of soluble high-molecular-weight $\mathrm{A} \beta$ oligomers is largely responsible for $\mathrm{AD}$ dementia and memory deficits in the $\mathrm{Tg} 2576$ mouse AD model (Cleary et al., 2005; Klyubin et al., 2005). Thus, major efforts from both academia and industry are presently focused on developing pharmacologic strategies that could delay the initiation and/or slow the oligomerization/ aggregation of amyloid peptide. Previous studies have suggested that some polyphenolic compounds could reduce brain amyloid neuropathology and improve cognitive function by promoting nonamyloidogenic $\alpha$-secretase activity (Rezai-Zadeh et al., 2005; Wang et al., 2006). Marambaud et al. (2005) also reported that resveratrol, a natural polyphenol mainly found in grape and red wine, could reduce $A \beta$ by promoting intracellular $\mathrm{A} \beta$ degradation in vitro. Another study also suggested that a few select grapederived polyphenolics could reduce aggregations of synthetic $A \beta$ peptides in vitro (Porat et al., 2006). Our studies use a naturally derived grape seed polyphenolic extract and demonstrate its in vivo efficacy to attenuate $\mathrm{AD}$-type $\mathrm{A} \beta$ neuropathology in the Tg2576 AD mouse model. More importantly, we confirm that GSPEmediated reduction of soluble HMW oligomeric $\mathrm{A} \beta$ peptide levels in the brains of Tg2576 mice significantly attenuated cognitive deterioration. Future studies exploring mechanisms underlying the absorption and eventually GSPE-A $\beta$ pharmacokinetics and pharmacodynamics in the brain will clarify the role of GSPE in oligomeric $\mathrm{A} \beta$-mediated responses. Considering the safety profile of GSPE (Bentivegna and Whitney, 2002) and its efficacy in attenuating AD-type phenotype, this natural compound is immediately available to be tested in $\mathrm{AD}$ clinical settings to prevent or treat $\mathrm{AD}$.

\section{References}

Bentivegna SS, Whitney KM (2002) Subchronic 3-month oral toxicity study of grape seed and grape skin extracts. Food Chem Toxicol 40:1731-1743.

Bitan G, Lomakin A, Teplow DB (2001) Amyloid beta-protein oligomerization: prenucleation interactions revealed by photo-induced cross-linking of unmodified proteins. J Biol Chem 276:35176-35184.

Bitan G, Kirkitadze MD, Lomakin A, Vollers SS, Benedek GB, Teplow DB (2003) Amyloid beta-protein (Abeta) assembly: Abeta 40 and Abeta 42 oligomerize through distinct pathways. Proc Natl Acad Sci USA 100:330-335.

Callahan MJ, Lipinski WJ, Bian F, Durham RA, Pack A, Walker LC (2001) Augmented senile plaque load in aged female beta-amyloid precursor protein-transgenic mice. Am J Pathol 158:1173-1177.

Cleary JP, Walsh DM, Hofmeister JJ, Shankar GM, Kuskowski MA, Selkoe DJ, Ashe KH (2005) Natural oligomers of the amyloid-beta protein specifically disrupt cognitive function. Nat Neurosci 8:79-84. 
Dorozynski A (1997) Wine may prevent dementia. BMJ 314:997.

Hardy J, Selkoe DJ (2002) The amyloid hypothesis of Alzheimer's disease: progress and problems on the road to therapeutics. Science 297:353-356.

Ho L, Qin W, Pompl PN, Xiang Z, Wang J, Zhao Z, Peng Y, Cambareri G, Rocher A, Mobbs CV, Hof PR, Pasinetti GM (2004) Diet-induced insulin resistance promotes amyloidosis in a transgenic mouse model of Alzheimer's disease. FASEB J 18:902-904.

Hsiao K, Chapman P, Nilsen S, Eckman C, Harigaya Y, Younkin S, Yang F, Cole G (1996) Correlative memory deficits, Abeta elevation, and amyloid plaques in transgenic mice. Science 274:99-102.

Kawarabayashi T, Younkin LH, Saido TC, Shoji M, Ashe KH, Younkin SG (2001) Agedependent changes in brain, CSF, and plasma amyloid $\beta$ protein in the $\operatorname{Tg} 2576$ transgenic mouse model of Alzheimer's disease. J Neurosci 21:372-381.

Klein WL (2002) Abeta toxicity in Alzheimer's disease: globular oligomers (ADDLs) as new vaccine and drug targets. Neurochem Int 41:345-352.

Klein WL, Krafft GA, Finch CE (2001) Targeting small Abeta oligomers: the solution to an Alzheimer's disease conundrum? Trends Neurosci 24:219-224.

Klein WL, Stine Jr WB, Teplow DB (2004) Small assemblies of unmodified amyloid $\beta$-protein are the proximate neurotoxin in Alzheimer's disease. Neurobiol Aging 25:569-580.

Klyubin I, Walsh DM, Lemere CA, Cullen WK, Shankar GM, Betts V, Spooner ET, Jiang L, Anwyl R, Selkoe DJ, Rowan MJ (2005) Amyloid beta protein immunotherapy neutralizes Abeta oligomers that disrupt synaptic plasticity in vivo. Nat Med 11:556-561.

Lambert MP, Barlow AK, Chromy BA, Edwards C, Freed R, Liosatos M, Morgan TE, Rozovsky I, Trommer B, Viola KL, Wals P, Zhang C, Finch CE, Krafft GA, Klein WL (1998) Diffusible, nonfibrillar ligands derived from Abeta1-42 are potent central nervous system neurotoxins. Proc Natl Acad Sci USA 95:6448-6453.

Luchsinger JA, Tang MX, Siddiqui M, Shea S, Mayeux R (2004) Alcohol intake and risk of dementia. J Am Geriatr Soc 52:540-546.

Marambaud P, Zhao H, Davies P (2005) Resveratrol promotes clearance of Alzheimer's disease amyloid-beta peptides. J Biol Chem 280:37377-37382.

McLaurin J, Kierstead ME, Brown ME, Hawkes CA, Lambermon MH, Phinney AL, Darabie AA, Cousins JE, French JE, Lan MF, Chen F, Wong SS, Mount HT, Fraser PE, Westaway D, St George-Hyslop P (2006) Cyclohexanehexol inhibitors of Abeta aggregation prevent and reverse Alzheimer phenotype in a mouse model. Nat Med 12:801-808.

Morelli L, Bulloj A, Leal MC, Castano EM (2005) Amyloid beta degradation: a challenging task for brain peptidases. Subcell Biochem 38:129-145.

Morris R (1984) Developments of a water-maze procedure for studying spatial learning in the rat. J Neurosci Methods 11:47-60.

Oda T, Wals P, Osterburg HH, Johnson SA, Pasinetti GM, Morgan TE, Rozovsky I, Stine WB, Snyder SW, Holzman TF, Krafft GA, Finch CE (1995) Clusterin (apoJ) alters the aggregation of amyloid $\beta$-peptide $\left(\mathrm{A} \beta_{1-42}\right)$ and forms slowly sedimenting $\mathrm{A} \beta$ complexes that cause oxidative stress. Exp Neurol 136:22-31.

Orgogozo JM, Dartigues JF, Lafont S, Letenneur L, Commenges D, Salamon R, Renaud S, Breteler MB (1997) Wine consumption and dementia in the elderly: a prospective community study in the Bordeaux area. Rev Neurol (Paris) 153:185-192.

Percival SS, Sims CA (2000) Wine modifies the effects of alcohol on immune cells of mice. J Nutr 130:1091-1094.
B

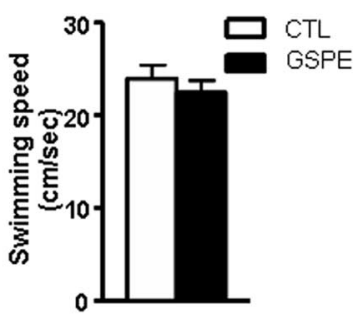

Figure 3. Treatment with GSPE attenuates cognitive deterioration in $\mathrm{Tg} 2576$ mice coincidentally with decreased extracellular 列 oligomeric $A \beta$ peptides in a dot blot analysis. $\boldsymbol{E}$, Inset, Representative dot blot analysis of HMW soluble $A \beta$ contents. Values CTL GSPE
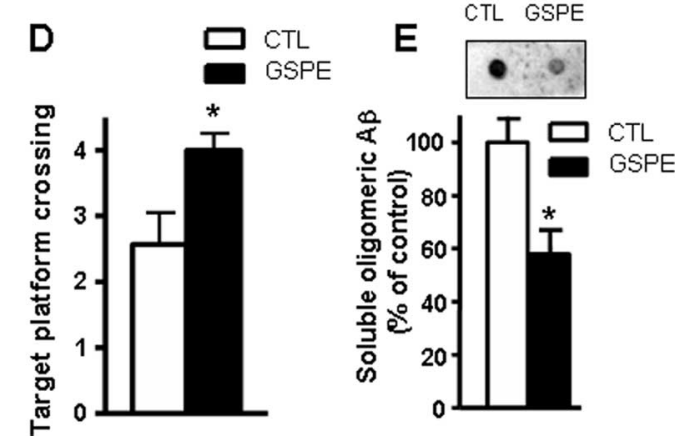

Porat Y, Abramowitz A, Gazit E (2006) Inhibition of amyloid fibril formation by polyphenols: structural similarity and aromatic interactions as a common inhibition mechanism. Chem Biol Drug Des 67:27-37.

Rezai-Zadeh K, Shytle D, Sun N, Mori T, Hou H, Jeanniton D, Ehrhart J, Townsend K, Zeng J, Morgan D, Hardy J, Town T, Tan J (2005) Green tea epigallocatechin-3-gallate (EGCG) modulates amyloid precursor protein cleavage and reduces cerebral amyloidosis in Alzheimer transgenic mice. J Neurosci 25:8807-8814.

Scalbert A, Williamson G (2000) Dietary intake and bioavailability of polyphenols. J Nutr 130:2073S-2085S.

Selkoe DJ (2001) Alzheimer's disease results from the cerebral accumulation and cytotoxicity of amyloid beta-protein. J Alzheimers Dis 3:75-80.

Siva B, Edirisinghe I, Randolph J, Steinberg F, Kappagoda T (2006) Effect of polyphenolics extracts of grape seeds (GSE) on blood pressure (BP) in patients with metabolic syndrome (MetS). FASEB J 20:A305.

Vinson JA, Proch J, Bose P (2001) MegaNatural ${ }^{\circledR}$ Gold grapeseed extract: in vitro antioxidant and in vivo human supplementation studies. J Med Food 4:17-26.

Vollers SS, Teplow DB, Bitan G (2005) Determination of peptide oligomerization state using rapid photochemical crosslinking. Methods $\mathrm{Mol} \mathrm{Biol}$ 299:11-18.

Wang J, Ho L, Qin W, Rocher AB, Seror I, Humala N, Maniar K, Dolios G, Wang R, Hof PR, Pasinetti GM (2005) Caloric restriction attenuates beta-amyloid neuropathology in a mouse model of Alzheimer's disease. FASEB J 19:659-661.

Wang J, Ho L, Zhao Z, Seror I, Humala N, Dickstein DL, Thiyagarajan M, Percival SS, Talcott ST, Pasinetti GM (2006) Moderate consumption of Cabernet Sauvignon attenuates Abeta neuropathology in a mouse model of Alzheimer's disease. FASEB J 20:2313-2320.

Weinreb O, Mandel S, Amit T, Youdim MB (2004) Neurological mechanisms of green tea polyphenols in Alzheimer's and Parkinson's diseases. J Nutr Biochem 15:506-516. 